\title{
Social Policy and the Income Structure of the Elderly in Hungary
}

\author{
ZSUZSA SZÉMAN \\ Scientific Research Worker \\ Institute of Sociology \\ Hungarian Academy of Sciences
}

\section{Introduction}

In Hungary the proportion of the retired is approaching one quarter of the population. Since the age limit for retirement is five years lower for women and their life expectancy higher than that for men, women by far outweigh men among the elderly: their proportion is about two to one.

Although more than half of the elderly have one or more chronic diseases, a great number of the retired, both men and women, are working. About 17 percent of the elderly and almost two-thirds of the aged have at least some supplementary income from the so-called second economy (the informal sector like gardening, auxiliary farms, etc.). The latter type is especially prevalent among the elderly in the rural area, where almost half of the aged live. The primary reason for having an extra job is an endeavour to compensate for inflatory losses in their incomes.

There is a controversial process going on in present day Hungary. On the one hand, as a consequence of the gaps in social policy, many of the elderly are simply forced to work. On the other hand, while the liberalisation of the economic policy may open up new ways also in post-retirement employment, the same policy, in practice, often results in a drive to oust the elderly from the labor market - usually under the slogan of economic efficiency.

The present paper sets out to explore four issues: What are the impacts of social policy on the standard of living at retirement age? Why do elderly people with a pension look for jobs? Who are the job-seekers? And what happens to them, if they fail in finding a suitable job?

\section{Pensions and income of the elderly}

In 1975 the new social security legislation defined pensions without adjusting them to yearly inflation rates. It provided for an annual automatic increase of two percent, which was about sufficient in those days, but insufficient to offset inflationary losses in the eighties.

By the late seventies, however, this kind of compensation was surpassed by a higher inflation rate. This process accelerated during the eighties. The elderly, in general, were most adversely affected by these developments. Being retired has become nearly synonymous with being poor. Even if people retire with relatively high pensions, they are likely to become poor in a couple of years because of a steady decrease in the real value of their pensions. Among so-called industrial pensioners the average loss in real value for the five years between 1980-1985 was 17 percent, but the same loss in the case of the relatively high pension group was 28 percent. (Forgács, 1985, 51). 
Policy measures were taken, in order to compensate for the loss in the real value of pensions, but the problem has been persistent: the living standard of the elderly has continually declined with an increasing proportion of those aged 70 or older near or below the poverty line. (Széman, 1988, 123). This has been the general trend in spite of repeated compensatory measures for this age category in 1985-1988.

For the reasons mentioned, the majority of the Hungarian elderly are compelled to look for auxiliary employment. Their financial situation is, however, not a result of old age alone. The type of pensions, gender, health, regional background, other components of income, comparative living expenses and their housing situation also affect their situation.

The largest pension is received by so-called work-related pensioners. People retiring from agriculture have, in general, lower pensions than persons retiring from industry.

There are major differences between work-related and widow pensions. About 13 percent of the elderly get widow pensions (KSH, 1985, 437). This latter type of pension is, however, rather small, 50 percent of the pension of the late spouse. Since widows tend to continue having the same housing expenses they had when their spouses were alive, and only relatively few of them have a chance for compensatory employment, many of the recipients of widow pension are living near the poverty line.

Another 13 percent of the elderly have no pension because they have not been employed or employed for a time too short to be entitled to a pension (KSH, 1985, 437). In Hungary there is no state pension system, e.g. as in Scandinavia. Hungarian family law obliges family members to support aged members financially. The per capita income of households where only the husbands are entitled to a pension is so low that they sporadically receive a small state assistance. Even with this assistance these families live from hand to mouth.

Hence, at least one quarter of the elderly have to face very harsh living conditions, especially if they have to do without supplementary income. Taking into account that retired husbands are obliged to share their pensions with their wives, it is apparent that many retired men have to look for an additional source of income.

Another disadvantage confronting aged women goes back to inequalities among pre-retirement salaries. These are considerably lower for women than for men for various reasons, i.e. a shorter working life, less schooling, etc. The average pension of women amounts to no more than 70-74 percent of the average pension of men (Forgács, 1988, 170). At the same time, among the elderly employed the ratio of women is only 40 percent. When reaching retirement age, women tend to have traditional tasks within the family, such as nursing and running the household, also true for working daughters or daughters-in-law, etc. Therefore women's chances for receiving a personal income are smaller than those of men.

The average pension of tne invalid is about $95-96$ percent of the average workrelated pensions (Forgács, 1988, 170). About one-fifth of the pensioners belong to this category. They are labelled as pensioners and in many ways treated similarly to the elderly, though their average age is much lower. Old-age and invalid pensioners and an additional two percent who, instead of a pension get only »regular relief» comprise about 30 percent of the total population.

For the reasons mentioned, it has been typical for pensioners to do their best in order to have additional sources of income. In the 1980 s only about one-third of the elderly have had pensions as their sole source of income (KSH, 1986, 72).

Inspecting the structure of total incomes in urban areas, it has been found that for many, 40-50 percent of their income is derived from complementary sources (Lévai, 1988, 194-195). In rural areas much of their food is produced and/or processed by the elderly themselves (KSH, 1986). 
By 1987 already more than 26 percent of the aged population lived under the social minimum. About 85 percent of the elderly received less than the average pension (KSH, 1987, 250, 252). This decline in the living standards has been closely related to the rising price rate, especially of basic necessities.

Relatives and family members do help the elderly, but nowadays the younger generations are also under growing pressure. At the national level the real value of the wages for 1988 was equal to that for 1973 .

The Hungarian social policy has not yet adequately met these challenges. The elderly have been given, on an increasing scale, so-called irregular social assistance, when they do not have any family members to take care of them. In 1988 about 13 percent of all the elderly received it at least once (Széman, 1988, 129). As these figures amply indicate, the typical bottlenecks of the living conditions of the aged are beyond the present day social policy. It is often said that before a new comprehensive social security system is realized, the solution to the problem of the aged is to work for extra income after retirement. However, it should be underlined that it is not likely that it would be possible to rely on this practice.

\section{Retired elderly on the labor Market}

The gradual disappearance of the elderly from the labor market coupled with the growing inadequacy of the established social policy will result in disastrous consequences for the aged population. In order to examine the labor market displacement, the years 1987 and 1988 have been used. In 198776 and in 1988128 elderly persons were interviewed in Budapest.

At the same time the national statistical data of the Labor Exchange relevant to the retired were analysed. Finally economic organizations registered in the Labor Exchange were grouped into three major categories, from each of which small random samples were taken for subsequent enterprise-level interviewing. In addition, an interview was made with the head of the Labor Exchange office. First, a short overview of the changing attitudes of the enterprises will be presented.

Until now post-retirement employment has been important, not only for the elderly, but also for the economy in general. Retired persons in 1985 accounted for about four percent of the Hungarian economy's work-time fund (absolute volume of wages). Several branches of the economy simply could not have done without the elderly: seven percent of the employees in sectors such as public health, domestic trade and foreign trade were pensioners. Four percent of the workers in industry, construction and transportation were retired people; many of the teachers in elementary schools were elderly, too. (Lévai, 1985, 62-63).

However, data from Labor Exchange offices indicate a diminishing trend in the demand for labor in the economy for the last two years. In the beginning of 1988 only about two-thirds of the earlier vacancies were available. During the same time the number of unemployed almost doubled, and also the Labor Exchange office studied was visited by $50-70$ percent more retired people in the second half of 1987 than a year before. Much of this job-seeking was motivated by anticipated rises in the inflation rates. Only about half of the applying pensioners succeeded in getting a job during the year, at least through the office. The reason was very simple: about half of the aged applicants were either ill, or invalids, or they were older than 65 . People in these groups were looking for jobs like that of a night watch, receptionist, clerk, etc. or some »easy» job, traditionally underpaid, but part-time and suitable for the retired. 
Simultaneously, however, a change took place in the structure of vacancies. In 1988, many enterprises demanded retired people only for skilled work, (carpenter, ironworker, roofer, locksmith, housepainter, nurse, etc.), or they needed semi-skilled labor, with a physical workload usually beyond the capabilities of the retired.

These combined effects resulted in an increasing hopelessness on the part of the elderly. Supplementary employment was ceasing to be a feasible alternative for improving their fast declining living conditions.

Until 1988 there used to be two major and officially declared motives for employing retired people in large scale enterprises: one rooted in economic rationality, and another so-called »socio-political» one, derived from humanistic values. The rationale behind this was the so-called average-level regulation of wages. Some categories of employees could get relatively high salaries only at the expense of employing quite a number of people (»wadding» in factory slang) with far-below-average wages. In general many of the elderly could not but accept the role of »wadding», while the enterprises could claim that they filled a gap in the existing system of social security, by providing employment, and thus supplementary income, to many elderly.

Recently, however, much has changed. New economic regulations, including a tax system along with an incentive wage system, have brought about a definite erosion in the social policy functions of the firms. The strengthening of the market mechanisms, the emphasis on efficiency and productivity - in the absence of the essential ingredients for a mature market economy - have worked heavily against the elderly.

Enterprises began to demand full-time labor instead of part-time, skilled labor instead of unskilled, etc. Parallel to these developments, children of the baby boom of the late sixties and early seventies began to enter the labor market. As a consequence, firms began to replace their aged labor force already in 1987 . The same tendency continued in 1988, reinforced by additional economic incentives. Enterprises were permitted to raise their wage-level only by $2-5$ percent, while the inflation rate rose to 18 percent a year. Where the so-called wage-fund regulation was introduced, a higher wage-raise was feasible at the expense of firing the elderly. Considering these circumstances it is a wonder that the number of retired employees declined in all the firms studied by only $9-31$ percent.

Some pensioners were saved by personal connections or social care of the traditional kind. The management in some enterprises decided for a ten percent reduction in pensioners, and, on lower echelons, the decision was »translated» into shorter working hours with all the pensioners saved.

Another kind of exception was that in some »trades of shortage», e.g. among carpenters, old people were preferred to younger ones.

The two ends of the social spectrum are notably absent from the labor market: those with very low pensions e.g. unskilled and very old people, especially women, and those with a relatively high education, high income and relatively recent retirement. The latter are absent from the labor market not necessarily because they, or members of their family, do not need any additional income; they have been reluctant to work especially since the introduction of the personal income tax. If they want to have the same net amount they had before the introduction of the income tax, companies have to pay them $30-35$ percent more. It is less expensive to look for active employees. Many enterprises tend to prefer the young, even if they have to be trained on the job.

Almost needless to say, technological development has contributed a lot to the same effect. The elderly have had diminishing chances especially in telecommunica- 
tion and transportation due to the spread of new electronic technology they were not accustomed to.

In the last few years pensioners' re-employment practices have changed considerably. In the past, the majority of pensioners who entered re-employment used to do so after a few years' retirement. Nowadays retired persons are more likely to retain their pre-retirement jobs, if they can, or to apply for a pensioner's job right after retirement. In order to remain employed as a pensioner, they are ready to accept unfavorable jobs more often. On the other hand, provided a firm is in need of employing pensioners, former employees are often preferred to retired employees contracted straight from the Labor Exchange.

If employment continues directly after retirement, it may adversely affect the person's state of health and endanger re-employment in the long run. A rise in the death rate of the 60-64 and 65-69 age groups of males between 1965-1985 (from .02440 to .03235 and from .03906 to .04390 , respectively) (KSH Demographic Yearbooks 1965-1985) may be, at least in part, attributable to omitting the earlier customary relaxation period right after retirement.

While for 60-64-year-old Hungarian males the age-specific death rate was 1.25 between 1976-1984, the comparable figure was 0.96 in neighboring Austria, 0.91 for Sweden, 0.86 for the Netherlands and 0.88 for Greece (United Nations Demographic Yearbooks, cited by Elwood Carlsson, manuscript; the indices for Austria, Sweden and Greece cover the period 1976-1983). Deterioration is most alarming in the case of aged men whose rate for continued employment is about double of that of women: even the originally lower female death rate for the 60-64-age group rose only slightly from 0.01425 in 1965 to 0.01479 in 1985 , while for the $65-69$-age group a drop actually occurred from 0.02540 to 0.02336 in the same period.

As for the working morale of the elderly, representatives of the enterprises studied acknowledged that it was better than that of younger age groups in the active labor force; they added, however, that the higher morale of those over 65 usually could not offset, in economic terms, the unfavorable effects of the labor of retired persons.

The second group of enterprises channelling their demand to the Labor Exchange in 1988 for the first time consists of relatively small companies having about a hundred employees. These firms tend to be of fairly recent origin and are pushed to higher rates of performance also by centrally imposed regulatory constraints. Thus, these firms did not have a tradition of re-employing retired people on whumanitarian» grounds, neither could they afford doing so because of the stringent economic conditions they are facing at present. They are driven partly by imposed policies and by the long-term uncalculability of the same policies, into a situation in which labor has merely economic significance. Though in some aspects their elbow room is larger than that of big enterprises, i.e. room for more flexibility in time and labor allocation, less overhead expenses, etc., they are unlikely to provide jobs for the elderly ousted from the large-scale segment of the labor market.

The third group in our scheme, enterprises whose demand for old labor was growing in 1988 as compared with 1987 mainly includes hospitals and health care institutions. Interviews with a chief nurse and a personal officer in a hospital revealed that the increasing demand of retired labor was largely an artifact, i.e. to a large extent superficial and as such deceptive. It was generated by obeying administrative regulations obliging these organizations to announce more vacancies. Since many of the jobs were rather demanding, both physically and mentally, and only a few of the retired could manage such a work load, they were exposed to the growing dissatisfaction of both their employer and clients. In addition, working conditions in the 
health services - in general - are severely inadequate, jobs underpaid, prestige low, with all its impact on the work process. Under these circumstances, it is understandable that having a job in these institutions tends to be a last recourse for both parties - for both the employer and the elderly.

\section{The experience of the elderly}

An overwhelming majority -70 percent of the elderly interviewed in the project mentioned an insufficient pension as a motive for seeking post-retirement employment.

Another proof that the primary motive of the elderly for re-employment was the lack of a proper income, was that about half of those seeking a job would have preferred living on their pensions alone - had it been enough for making a decent living.

It can be taken as a trend-indicator that in 1988 there were eight percent more people who evaluated their own health condition as »varying», "poor» or »bad» than in the first sample (40 instead of 32 percent).

If we keep in mind that only about half of the applicants find a job through the Labor Exchange for the Retired, and those aged over 65 are seldom accepted by enterprises for employment, the evidence makes bottlenecks in the social security system more apparent. In the 1988 sample there were significantly more applicants even from distant regions than in the 1987 sample - to no avail. They are primarily from counties with rising unemployment rates.

\section{Conclusions}

To sum up, there is a growing incompatibility between the structure of the postretirement labor supply and demand. This incompatibility is growing, when postretirement employment is becoming the sole and last recourse for an increasing number of the elderly to subsist. It should be equally clear that without well-meant and wellimplemented policy intervention the onset of a great social catastrophe is inevitable.

It is to be kept in mind that the realization of any economic policy reform both in theory and practice without a simultaneous overhaul of the social security system is in the long run bound to be counterproductive. In more concrete terms, it implies that - instead of a hopeless struggle with the cumulated effects of wage regulation, the tax system and inflation rates, etc. - a new pension system should be introduced. Further it should be properly adjusted to the economic reforms and include a guaranteed social minimum pension as well as a more equitable distribution of a radically enlarged pension fund.

\section{References}

Forgács, A. (1985) A nyugdijrendszer fejlödése és problémái Magyarországon (Development and problems of the pension system in Hungary). In: Szociálpolitikai Értesitö/3, pp. 35-52. Budapest : MTA Szociológiai Kutató Intézet

Forgács, A. (1988) Nyugdijrendszerunk fejlödése és problémái (Process and development of the pension system, its problems). In: Nyugdijkorhatár?, pp. 157-176. Budapest: Kossuth.

KSH (Kozponti Statisztikai Hivatal) (1985) Az 1984. Évi mikrocenzus adatai (Data from the 1984 microcensus). Budapest. 
KSH (Kozponti Statisztikai Hivatal) Statisztikai Évkönyvek 1965-1985, 1987 (Statistical yearbooks 1965-1985, 1987). Budapest.

KSH (Kozponti Statisztikai Hivatal) (1988) Az idöskorúak helyzete (On the situation of the elderly). Budapest.

Levai, J. (1985) Munkavállalás, foglalkoztatás, szociális ellátas. (Employment, work at retirement, social support). In: Szociálpolitikai Értesitö/3, pp. 54-97. Budapest: MTA Szociológiai Kutató Intézet.

Levai, J. (1988) Segits magadon! (Help yourself - at retirement!). In: Nyugdijkorhatár?, pp. 177-202. Budapest: Kossuth.

Széman, Zs. (1988) Az idöseket elláto intézményrendszer (The system of institutions providing care for the elderly). In: Nyugdijkorhatár?, pp. 121-155. Budapest: Kossuth.

United Nations Demographic Yearbooks, cited by Elwood Carlsson, unpublished manuscript (the period of 1976-1984). 